\title{
CNRS returns fire on ethics review panel
}

[PARIS] Institutional arrangements within France's public research agencies often encourage the politicization of decisionmaking, as well as nepotism and cronyism, according to an ethics committee set up by the Centre National de la Recherche Scientifique (CNRS), Europe's largest basicresearch agency.

These conclusions are contained in a critical report, Ethics and Scientific Institutions, released in Paris last week. But the report has already sparked controversy over the role of the committee itself, with some senior science administrators arguing that questions about the organization of research are beyond its remit and competence.

The committee, known as COMETS, is chaired by Hélène Ahrweiler, a historian and president of the Paris-based University of Europe. It was set up to identify ethical problems in areas other than biology and medicine (see Nature 370, 88; 1994). Its 14 members include Hubert Curien, a former research minister, and Jean Dausset, 1980 Nobel prizewinner in physiology or medicine.

Its report emphasizes that, overall, the French research system works well. But,

acknowledging that it is focusing on 'black spots', the report is particularly critical of the research organizations' executive boards. These bodies are made up of public personalities, leaders of industry and representatives of the government and trade unions, and in principle wield considerable power, as they approve all budgetary decisions, and define the agencies' research strategy.

The report says the boards of the research agencies are failing to exercise their powers of oversight, in particular in the choice of research strategy. Real power tends to be concentrated in the hands of the offices of the director-generals of the research agencies and the research ministry, according to the report, which claims that the boards often do little more than rubber-stamp decisions.

The boards of agencies such as CNRS should speak out on strategic issues, says the report. It claims that many major decisions are taken behind closed doors, allowing lobby groups to flourish, in particular in defining 'big science' projects. Edouard Brezin, president of the CNRS board, concedes that it is "a pity we are not consulted on strategy before decisions are taken; we are often asked to vote

\section{US budget plans jeopardize role in ITER}

[WASHINGTON] A key congressional budget committee will this week consider fresh and drastic cuts in fusion research which could lead to the abrupt withdrawal of the United States from the International Thermonuclear Experimental Reactor (ITER) project.

Early drafts of the appropriations bills for the 1998 financial year (starting in October), to be finalized on 11 July by the energy and water appropriations subcommittee in the House of Representatives, would cut the Department of Energy's fusion research programme from \$225 million to \$175 million, according to administration officials.

The proposal would take most of the $\$ 50$ million cut from the US contribution of $\$ 55$ million to ITER. That would effectively end US participation in the engineering design assessment phase of the project nine months before its completion next July (see Briefing, on page 115).

One administration official says that the corresponding Senate subcommittee is considering a similar cut, but many fusion supporters expect the Senate to be more supportive than the House.

Rumours of the proposed cut stunned the fusion community, which experienced deep budget cuts in 1995. "This is still a rumour, but we are taking it very seriously," says Anne Davies, head of the fusion programme at the energy department. "I'm shocked that this could even be considered."

Jack Gibbons, science adviser to

President Bill Clinton, was this week making contact with Joe McDade (Republican, Pennsylvania), chair of the House subcommittee, and Pete Domenici (Republican, New Mexico), chair of the Senate panel, to appeal for the administration's $\$ 225$ million request for fusion research to be met.

Staff on both subcommittees declined to comment in detail on their plans, but confirmed that they may pay particular attention to ITER because its construction has been delayed by the international partners (see Nature 387, 746; 1997).

In theory, the numbers drawn up by the staff have little significance until they are considered by the subcommittees. But in practice it can be difficult for members to find money to restore cuts proposed by staff.

Administration officials will argue that the United States has a commitment to its partners - Europe, Japan and Russia - to complete its share of ITER research. But this did not count for much in 1995, when the Congress cut the US contribution from $\$ \mathbf{8 0}$ million to $\$ 55$ million. Fusion lobbyists worry that few members of the appropriations panels are sufficiently committed to fusion, or to ITER, to find $\$ 50$ million from other programmes to support it. afterwards simply as a legal requirement".

To remedy the situation, the report suggests that boards be given greater independence, pointing out that the representatives of the ministry on boards currently have a right of veto, which sharply curtails the boards' autonomy.

The report also criticizes the procedure used to appoint senior staff. The directorgenerals of research agencies are nominated directly by government. They then nominate other senior staff directly in consultation with the ministry. The report recommends that the executive boards of the agencies should set up search committees to propose candidates for appointments.

The lack of such committees is the "French tragedy par excellence", asserts one member of the ethics committee, arguing that this results in excessively politicization of nominations for senior posts. "The power to nominate is decisive in France; by nominating people we make them our debtors," he adds.

Meanwhile, the release of the report has sparked a row over the role of the ethics committee itself. The three-year mandate of current members of COMETS expired last month, and CNRS has now decided to review the committee's functions, one idea being to replace it with a national committee. CNRS is holding discussions with the research ministry, and a decision on the committee's future is expected at the autumn meeting of the CNRS board.

Brezin argues that the committee's report overstepped its remit, and that its contents concern organizational matters that have "nothing to do" with ethics. While agreeing that there are "elements of truth" in the report, he claims that its conclusions are too simplistic, and that the committee's members lack sufficient "competence" to address such issues. Brezin says he would be open to an audit of "legitimate questions" concerning the running of French research, on condition that this "be done seriously by competent people".

One member of COMETS claims that the decision to restructure the committee stems in part from the fact that the report's criticisms have not been appreciated by senior CNRS management. CNRS's action, he claims, is a thinly veiled warning to their successors on whatever form of committee emerges that "they don't have the right to make too severe criticisms".

Brezin dismisses these claims, arguing that the decision to review the status of the committee at the expiry of the current members' mandates was logical, particularly given the arrival of the new government. "There is no intention to abolish or suspend the committee," he says.
DeclanButler 